\title{
THE NEED OF STRENGTHENING THE PEDAGOGICAL COMPETENCIES IN TEACHING FROM THE ENGLISH TEACHERS' PERSPECTIVE
}

\author{
MA Violeta Panev, Primary School V.Tasevski - Skopje, Republic of Macedonia \\ E-mail: lingva@mt.net.mk \\ Dr. Aneta Barakoska, Faculty of Philosophy, Ss.Cyril and Methodius University - Skopje, \\ Republic of Macedonia \\ E-mail: aneta@fzf.ukim.edu.mk
}

Received: May, 05.2015.

Accepted: May, 25.2015.

Original Article

UDK 371.12.011.3-051:811.111(497.7)

\begin{abstract}
The traditional concept of the teaching staff continually is expanding and changing not only in the content but in the methodology and in the forms of learning as well because of the permanent change of the social conditions and the advancement of the science and technology. The teacher is a mediator of the knowledge and a key person who realizes the reforms and the teaching processes into practice and that is why the present and the future requires from the teacher qualified, expert and fundamental pedagogical knowledge.

The competencies and the skills as a changeable category mainly recognized and focused on the enrichment and the personal development of someone who learns, besides the initial education implies flexibility as well. Even more it implies improvement of the skills and the knowledge according to the given time frame periods and life conditions by the science and the technology development. During the teachers' initial education there is a need of expanding their pedagogical skills and competencies in order the pedagogical function to be fulfilled in a modern world using the foreign language in the teaching process as a tool for an entry to new resources and innovative techniques of studying.

In the paper there is a presentation of a short comparison of the teachers' competencies in the English linguistic speaking areas and in Macedonia through comparing the educational programs of the higher faculty institutions and colleges. We will present their attitudes and opinions in terms of the level of the acquired competencies in the initial education. The results are to be used in the professional improvement of the teaching competencies of the English language and other subject teachers during their initial education. The research implemented with the teachers in the schools led to the conclusion that there is an immense need of expanding
\end{abstract}

Corresponding Author

MA Violeta Panev, Primary School V. Tasevski Skopje, Republic of Macedonia

E-mail: lingva@mt.net.mk the teachers' competencies during their initial education.

Keywords: Pedagogical competencies, Teachers of English, Initial education, Primary school.

\section{INTRODUCTION}

In a modern society, with increased dynamics of everyday changes that interact with the increase of human knowledge in all spheres of life especially in science and technology "the teacher of today" is faced with a lot of challenges in terms of professional capacity to improve the people's life. His role is undoubtedly a major and vital for the social good and there is much effort nowadays in dealing with the everyday challenges in teaching practice because social changes require expanding of the teacher's obligations and knowledge and possessing a wide range of teaching skills. Adequately trained teachers will comply with the modern teaching process and will lead to the desired results so the traditional concept of teaching profile constantly is expanding and changing both in content and methodology and in all forms of learning as well. The systematic development of the capabilities and skills of the teacher goes hand in hand with efforts to apply scientific achievements in teaching based on knowledge and scientific principles. The teacher is the mediator of the updated knowledge and the one who implements the reforms and changes in the educational process so the teaching today requires qualified professional and thorough pedagogical education. The teacher is a mediator between scientific knowledge and social tendency children to learn about the world around them, and "young generation is intended to gather the values through the system of 
education, aimed at development of the existing social system" (Barakoska, 2008).

During the education of teachers in Macedonia who teach English and other subjects as well, there is a need to broaden their pedagogical skills and competencies, in order to achieve their pedagogical function in a modern world using the foreign language as a tool to new sources and innovative teaching techniques. This paper will make a short comparative review of the pedagogical skills of teachers of English language in Macedonia and in English speaking countries. The findings of the survey conducted to 2014. will focus on the promotion of professional pedagogical competencies of teachers of English during their initial education. One goal of the paper is to encourage further research in the field of pedagogical skills of teachers in different subject studies.

The modern character of a teacher today covers a broad concept of a number of activities in and out of the school. All these tasks of the teacher through pedagogical educational components contribute to strengthening the human body and health, social life and concern for others around, as well for beauty, peace, harmony and creativity. The new democratic society requires from the teachers that a student from passive receiver of information and knowledge would grow into an independent organizer of his knowledge and an active citizen in the community.

Therefore besides vocational education teacher should have a thorough pedagogical education. His role is not only to present the knowledge of the subject field but also the ability to manage the complex process of adoption of the knowledge according to the pace and ability of the child and to develop and shape his personality to use the knowledge in the right way. The teacher is a citizen too. Pokonjak will emphasize that the person of the educator cannot be split and therefore his personal properties include the inventory of desired competencies and positive or negative characteristics focus on the two axes of his existence, a teacher - an educator and a person. (Potkonjak, 1968) The teacher is required to be skilled in his work, and the skills and the ability to interpret the knowledge in a manner and level accessible to students requires fundamental pedagogical competencies. Still, we are aware that even in the $21^{\text {st }}$ century, full of modern means of communication, information and knowledge transfer, the teacher is the key figure for the proper functioning of the learning process and formation of young people. His role as an "educator" undoubtedly is great and sacred.

The National Programme for the Development of Education in the Republic of Macedonia 2005-2015, in the Programme for professional development of the teaching staff, it is proposed that this issue should be raised and paid attention to for the long-term professional capacity of teachers in Macedonia in terms of the initial and continuing education and professional development. (National Programme for the Development of Education in Macedonia 2005-2015). Studies suggest changing the curricula of faculties of initial teacher education by supplementing and expanding the curricula. At the same time requirements are set on teacher qualifications or competence application of modern scientific achievements of educational theory and practice, which is modernization of knowledge. That means that the decision should be a new reinforcement of initial training and system for professional development of the teaching staff.

Hence the interest in the problems in this field study and the need for examination of practical experience and views of teaching realization of the objectives of the programs in English in primary education is done by the teachers themselves, from the teachers' perspective.

Therefore, a research was conducted in schools in order to examine the attitudes, opinions and experience of teachers of English in the implementation of the curriculum in terms of the adequacy of the acquired pedagogical competencies on the higher education institutions and their application in daily teaching practice.

The teacher is the central figure in the teaching process as the essential quality of education depends on his abilities, values and skills. Therefore any investment in human resource teachers is invaluable. Solution is seen in the expansion of the initial teacher education into a higher level in terms of pedagogy strengthening skills, permanent professional development and selection of suitable profiles for teacher profession.

\subsection{Short comparative study of the educational programs for teachers in Macedonia and England}

The teacher's competencies are founded in the initial education as a professional component that represents the skills and knowl- 
edge of a teacher in the subject he teaches and the pedagogical part. The ratio between these two parts in different educational systems is different. "For example in the USA and Japan, the ratio between these two components is $3: 1$, France $2: 1$, in Germany it is approximately equal, and in England-GB (teachers' colleges) the ratio is 2:3. In Macedonia it is at a very inappropriate level (Kamberski, 2000). This ratio clearly indicates that subject teachers acquire initial education which does not meet the needs of the teaching profession." (National Programme for the Development of Education in Macedonia 2005-2015).

If teachers did not study teaching and pedagogical subjects simultaneously at the faculty (in the last 2-3 decades the study consisted only of three courses subjects: pedagogy, psychology and methodology), it could be acquired through a pedagogical qualification at the same or other faculty. "It was important to get a formal certificate rather than professional knowledge, abilities and skills necessary to successfully perform the teacher's profession." (National Programme for the Development of Education in Macedonia 20052015). It is said that the Bologna process is of a particular importance in finding adequate solution to this problem. Changes that would occur in the initial English teacher training would lead to compatibility with programs for teacher training colleges and universities in England and would lead to a revival of an educational system that requires active and mobile professionals, initiative teachers who create together with their students and hold the "key competencies" required for modern teaching in the $21^{\text {st }}$ century.

The successful teacher of the $21^{\text {st }}$ century is constantly active and aware of the changes occurring in local and wider community and the world, so The European Commission of Education as priority points right to the teacher, his mobility, quality, efficiency and key competencies; the national education strategy of Republic of Macedonia as key issues appoints the identifying skills the teachers need to have and professional development programs for teacher training. The opportunity Macedonia to join the European family and citizenship requires not only teachers who are drivers of advancement and change but also who are direct participants in the change.

It is the reason why we decided to make a survey of the attitudes and opinions of the English teachers in particular about their acquired competencies in the initial education at the higher institutions.

\section{MATERIALS AND METHODS}

The object of the research is the initial teacher education and training in English language and the need of strengthening their pedagogical competencies at higher education institutions (state universities). The aim of the research is determining the need for more pedagogical subjects in the initial education study programs for teachers of English. The type of the research is fundamental, applied and contemporary, realized in a short time frame. The study is based on the results referring to the quantitative processing of the data through statistical analysis of the answers given by the teachers of English who teach English at primary schools. The respondents are 60 surveyed teachers from 20 primary schools in Macedonia.

The objectives of the study are to make a survey about the attitudes of teachers of English in terms of pedagogical courses in higher education curricula; whether they acquire enough general and specific competencies during their study of English language at the universities; in terms of the difficulties encountered in the teaching language process and in terms of strengthening the pedagogical competencies in the study programs at universities trough studying more pedagogical subjects.

General hypothesis: There is not sufficient content of pedagogical subjects courses in the university study programs for teachers of English in Macedonia.

\section{Supplementary hypothesis:}

1. The teachers of English consider there is a lack of pedagogical disciplines and course subjects in study programs for teachers of English;

2. They consider they do not possess sufficient pedagogical and specific competencies for the implementation of teaching English at school;

3. They consider that the increased number of pedagogical subjects courses will enhance the pedagogical skills of teachers of English.

In the research descriptive methods of analysis and synthesis were applied.

- Descriptive method is used to describe, explain, compare and generalize the phenomena of the subject of research, that is the initial teacher education and pedagogical contents;

- Comparative method is used in describing and comparing teacher education through educational programs for teachers of universities in Macedonia and England; 
- Analytical method is applied trough the analysis of the study groups and programs that produce teachers, the number of pedagogical subject courses and descriptions of the same with set goals and objectives, criteria and standards for obtaining qualified teaching status and necessary pedagogical competencies;

- Synthetic method is applied in the description of the education and training of future teachers as a whole in the educational systems for the realization of the need to strengthen their pedagogical competencies.

In accordance with the objectives, the research applies the Surveying, Questionnaire and Scaling in order to determine the level of acquisition of pedagogical competencies in teachers' initial education and to note the difficulties encountered as a result of insufficient acquired competencies during the education at the faculties for teachers.

\section{RESULTS AND DISCUSSION}

The questionnaire consists of closed multiple choice questions giving the possibility to the respondents to choose to what extent they agree with the statements; part of them are open ended questions and provide personal data and subjective opinions and attitudes of the teachers. They refer to the description of the curriculum structure of pedagogical disciplines and subjects that prepare teachers referring to the ratio between pedagogical-psychological training subjects and main subjects education. The data are going to be presented numerically and descriptively.

The first question intended for teachers of English is an open type and it is as follows: "What are the problems that you have met in the educational process when teaching English in terms of the necessary pedagogical competencies?" We received a number of responses referring to the general and specific competencies, and the list is quite long so the common challenges and obstacles in teaching pointed by the teachers are:

- Working with children with learning disabilities and different abilities and problems; special needs children;

- Gifted and talented students and individual educational plans and their implementation;

- Dealing with violence in the schools;

- Knowledge of the objectives of the curriculum of the corresponding subject and age;
- Knowledge of the Curriculum goals and programs created by institutional bodies;

- Ability to diagnose educational problems and applying appropriate pedagogical approach;

- Managing the pedagogical documentation and records;

- Possessing skills for data collecting in monitoring and evaluation of the educational work;

- Competence in using ICT educational technology related to the objectives of teaching English;

- Interaction in teaching and communicating with children and parents;

- Selection of an appropriate pedagogical model for different age groups and learning styles;

- Multiculturalism and language competence for integration multicultural and multilingual issues in teaching purposes;

- Use of the pedagogical aspect of textbooks and literature in education;

- Knowledge of the levels of an international Frame of Reference for languages; differentiating various international exams (KET, CFE, CAE, etc.);

- Professionalism and ethical principles in educational practice;

- Legislative obligations in the primary education;

- Capacity for interpersonal communication at all levels - teaching and collegial management.

The explanations of the teachers are presented in the order of quantity in their original version in order to have an authentic representation of the teachers' attitude. Furthermore on the list are the following statements:

- Pedagogical problems and discipline are a great challenge;

- Dealing with children with emotional and social problems;

- Learning Styles and tools, methods use for individualizing teaching;

- Dealing with vulnerable group of students, children with emotional problems, children with special needs, problem children, gifted students, etc .;

- Lack of quality mentoring and accompanying introduction to teaching;

- Evaluation and proper monitoring of the students;

- Deficiencies in the textbooks of English especially for classroom instruction;

- Coordination between educational state bodies in terms of school documentation;

- Making pedagogical records, coopera- 
tion with parents and their inclusion in educational process, counseling process, emotional groups, destructive behaviors, discipline etc;

- Curriculum planning, annual and thematic planning, law changes in the primary education;

- Assessment and record keeping;

- Skills for monitoring and evaluation in the educational process;

- Implementation of digital content and methodology in correlation to different age;

- Administration and additional teaching hours, number and distribution by grades;

- Skills for communication in a multicultural environment - children, parents;

- Capability to use modern didacticmethodological approaches at appropriate age;

- Development of the children's personality and theories of learning the language;

- Awareness of diversity of different age students and applying different tolerance strategies;

- Adoption of the principles of planning and organization of teaching;

- Knowledge of the code of ethics of the teacher and argumentation solutions.

As we can see the issues that teachers face in everyday practice in the statements as primary they note those related to the educational practice, i.e. related to the teaching; they feel the need for help and solving problems strategies after the graduation. On the list are the following:

- Skills application in planning and organization of the educational process; ronment

- Creating a stimulating learning envi-

- Innovation and use of teaching resources, application of modern teaching strategies, techniques and methods; implementation of strategies for effective teaching;

- Professional communication of a teacher and ethics issues, their initiation and resolution;

- Competence in using ICT technology related to the objectives of teaching English;

- Use of different sources of learning English: literature, poetry, texts, internet sites and others;

- Ability to foster critical and creative thinking in the educational process;

- The concept of lifelong learning and recognition of the need for additional education (CDP);

- Willingness to continuous personal and professional development through individual learning;

- Need for more practice directly related to the teaching process;

- Need for a thorough and long-term collaboration between the institutions which educate future teachers and schools in terms of practical work;

- It is necessary to introduce new subject pedagogical courses that will prepare future teachers.

The next question is also open one and refers to the number of pedagogical courses taught in the HE Department of English. The question is as follows: "How many pedagogical subjects were included in the study program for teachers?" The data are presented numerically to get a clearer picture of the number of pedagogical courses and academic programs that prepare teachers of English. The question is an introduction to the next question and connected with the hypothesis which claims the lack of pedagogical disciplines and courses in education study programs for future teachers. We see that most teachers in initial education studied 2 to 3 subjects directly related to teaching practice, i.e. the number of pedagogical subjects is fairly small. According to the table below, the majority of respondents $(67,21 \%)$ attended 3 subjects at the academic institution that educates teachers.

Table 1. How many pedagogical subjects were included in the study program for teachers?

\begin{tabular}{llrr}
\hline & & \multicolumn{2}{c}{ Response } \\
\hline \multirow{3}{*}{ Question } & $\begin{array}{l}\text { How many pedagogical subjects } \\
\text { were included in the study } \\
\text { program for teachers? }\end{array}$ & f & $\%$ \\
\hline & 1 subject & 1 & 1,65 \\
\cline { 2 - 4 } & 2 subjects & 11 & 18,03 \\
\cline { 2 - 4 } $\begin{array}{l}\text { Number of subjects } \\
\text { subjects }\end{array}$ & 4 subjects & 41 & 67,21 \\
\cline { 2 - 4 } & subjects & 5 & 8,19 \\
\cline { 2 - 4 } & more & 1 & 3,28 \\
\hline \multicolumn{2}{c}{ Total } & 61 & 1,64 \\
\hline
\end{tabular}

We assume that there is a mismatch between the different Higher Education Departments that educate teachers of English in terms of the number of teacher training subjects courses that are offered during the initial training, so that only $1.65 \%$ of the teachers have only one or more than 5 subjects in their study group, $18.03 \%$ teachers attended 2 subjects and $8.19 \%$ of respondents attended 4 subject courses.

The question number 3 is of an alternative type and tries to give a global overview of the issue in terms of the required number of pedagogical subject courses in the initial education or whether the current number represented has met the needs of teachers in the acquisition of pedagogical and specific competencies. The question is the following: "Do you consider this number of subjects to be sufficient? " 
We can see from the given results that teachers are expressing clearly the need for further study of pedagogical subjects in their study group in order to be prepared to meet the challenges of modern teaching. A great percentage of $90.16 \%$ believe that the current number of subjects in their pedagogical education study group is very low, and only $9.84 \%$ of respondents say that this number is sufficient. What emerges as a conclusion is the need of standardization of the different faculties study programs for teachers concerning the number of the pedagogical subjects studied.

Table 2. Do you consider this number of subjects to be sufficient?

\begin{tabular}{|c|c|c|c|}
\hline & & \multicolumn{2}{|c|}{ Response } \\
\hline Question & $\begin{array}{l}\text { Do you consider this number } \\
\text { of subjects to be sufficient? }\end{array}$ & $\mathrm{f}$ & $\%$ \\
\hline a. & Yes & 6 & 9,84 \\
\hline b. & No & 55 & 90,16 \\
\hline Total & & 61 & $100 \%$ \\
\hline
\end{tabular}

The table figures comply with the hypothesis which refers to the positive attitudes of teachers in terms of increasing the number of pedagogical subject courses.

The question number 4 is built upon the previous results and aims to confirm the necessity of new program teaching disciplines and subjects related to teaching and the education of future teachers. We conclude that even a larger number of respondents $90.16 \%$ consider the need for greater number of pedagogical subjects in the study programs that educate teachers of English. The question is alternative one and is as follows: "Do you think there is a need for additional pedagogical subjects in the study programs that educate teachers of English?

a. I consider they are insufficient

b. I consider they are sufficient".

The numerical display table is following:

Table 3. Do you think there is a need for additional pedagogical subjects in the study programs that educate teachers of English?

\begin{tabular}{|c|c|c|c|}
\hline & & \multicolumn{2}{|c|}{ Response } \\
\hline Question & $\begin{array}{l}\text { Do you think there is a need for additional } \\
\text { pedagogical subjects in the study } \\
\text { programs that educate teachers of } \\
\text { English? }\end{array}$ & f & $\%$ \\
\hline a. & Yes, I consider they are insufficient & 55 & 90,16 \\
\hline b. & No, I consider they are sufficient & 6 & 9,84 \\
\hline Total & & & 100 \\
\hline
\end{tabular}

In addition to the above conclusion and hypothesis are the results from the question number 5 in the questionnaire which relates exactly to the the increased number of pedagogical subject courses and the strengthening teachers' competencies. Satisfactory is the fact that most of those surveyed teachers are positive $(70.49 \%)$. The question is of a selective type and is as follows: "According to you, to what extent will the bigger number of pedagogical subject courses in education curriculum for English teacher enhance their pedagogical skills?

a. They will be strengthened a lot.

b. They will be partly strengthened.

c. They will not be strengthened at all."

The quantitative results on this issue are displayed in the table number 4.

Table 4. According to you, to what extent will the bigger number of pedagogical subject courses in education curriculum for English teacher enhance their pedagogical skills?

\begin{tabular}{|c|c|c|c|}
\hline & & \multicolumn{2}{|c|}{ Response } \\
\hline Question & $\begin{array}{l}\text { According to you, to what extent will the } \\
\text { bigger number of pedagogical subject } \\
\text { courses in education curriculum for } \\
\text { English teacher enhance their } \\
\text { pedagogical skills? }\end{array}$ & f & $\%$ \\
\hline a & They will be strengthened a lot. & 43 & 70,49 \\
\hline $\mathrm{b}$ & They will be partly strengthened & 16 & 26,23 \\
\hline c & They will not be strengthened at all. & 2 & 3,28 \\
\hline Total & & 61 & 100 \\
\hline
\end{tabular}

\section{CONCLUSION}

At the end of the analysis and interpretation of the questionnaire there is a need to summarize the results into a conclusion. Based on the data we make the following conclusive findings concerning the views of teachers about their pedagogical and specific competencies: teachers recognize their teaching skills and the need to extend them by studying additional pedagogical subjects and more disciplines in the study group for teachers at the Higher Institutions. They point out the lack of bigger part of the pedagogical necessary competencies in the initial education:

- Teachers do not acquire many competencies in terms of monitoring and evaluation of the educational work of all participants in the educational process;

- Most after graduation do not know the purpose of the curriculum objectives of the main subject for different age groups;

- They possess insufficient skills for innovation of the educational process and are not thoroughly trained to use the modern didactic-methodological approaches for the implementation of effective teaching strategies, methods and individualization in teaching;

- They are not sufficiently trained to create individual educational plans and to choose 
the ppropriate pedagogical model for a different educational group;

- Teachers after graduation do not feel ready to make pedagogical records and documentation in the school;

- Multicultural environment and communication at various levels (parents, children, and colleagues) is also a big challenge for the teachers;

- Teachers are not trained for business and professional performance in terms of commitment to moral principles in educational practice and professional ethics in communication and relationship issues;

- They are partially capable of applying the skills of planning and organization of the educational process;

- Teachers do not possess the competencies and knowledge in terms of the development of the childlren's personality and theories of learning the language according to the appropriate age;

- They do not feel confident in establishing correlation in the planning between the teaching of English and other subject areas;

- They know little about the International Reference Framework languages levels and skills;

- They need a more reflexive practice and commitment to the integration of multicultural and multilingual competence in teaching aims;

- They are not familiar with the primary education legislation;

- Very few are prepared for continuous personal and professional development;

- They encounter a lot of difficulties when working with special needs children and creating individual learning plans, violence in the schools, educational issues, information technology and administration, communication with parents and counseling procedures etc.

Based on the analysis, description and interpretation of the results we conclude that the hypothesis are fully confirmed. We consider necessary to provide recommendations and guidance on strengthening the pedagogical competencies of future teachers of English:

1. Change in curricula programs at higher education institutions:

- Regarding the pedagogical subjects courses and increase their number and the need to correlate them with other discipline courses study for teachers;

- A change in the program objectives in the preparation of future teachers regarding several related disciplines; students in all de- velopment phases; professional tasks and criteria; educational bodies, authorities, institutions and environment;

- Strengthening the pedagogical skills of teachers by introducing special subjects that will provide the knowledge, skills and abilities to work with students with special needs and difficulties in learning; skills for communication in a multicultural environment; keeping the pedagogical documentation and records and more;

- Cooperation with educational bodies outside the country and share experiences concerning related program curriculum objectives of the study groups preparing teachers.

2 . Amendments and changes of the educational practice and evaluation of a teacher:

- Increase the time frame of the practical training of teachers and its expansion within the primary education (from the first to the ninth grade);

- Establishment of multi-merit system of evaluation of teachers who will be supported adequately depending on the level of the professional development from the entry status as a newly - qualified teacher to the high scale of professional teaching employee with systematic evaluation by senior mentor teacher.

3. Specifying the criteria and standards for professional teacher status and quality teaching.

4. Additional forms of training the teachers as a result of insufficient pedagogical competencies acquired in initial education and teaching practice.

These recommendations are the starting points for further research in other faculty study groups that educate future teachers and for the reforms in general:

- Research in the other teaching faculties language groups and subject areas;

- Establishing standardized taxonomy of competencies (pedagogical and specific) of subject teachers towards the criteria for excellence in teaching;

- Continuous motivation for lifelong learning and objective evaluation of the quality of a teacher;

- Improving the educational process and the status of the teacher of the $21^{\text {st }}$ century.

Conflict of interests

Authors declare no conflict of interest.

\section{REFERENCES}

Баракоска, А. (2008). Вредностите и образованието во услови на општествени промени. Годишен 
(IJCRSEE) International Journal of Cognitive Research in Science, Engineering and Education

Vol. 3, No.1, 2015.

зборник. Скопје: Институт за педагогијаФилозофаски Факултет, Скопје. Retrieved from http://fzf.ukim.edu.mk/files/zborn$\mathrm{ik} / 02 \% 20-\% 20$ Godisen $\% 20$ zbornik\%20br.\%20 61\%20(2008)/FzF2008-01\%20Barakoska.pdf

Bologna Declaration. Retrieved from http://www.ond. vlaanderen.be/hogeronderwijs/bologna/documents/MDC/BOLOGNA DECLARATION1. pdf

Department for education of the UK. Retrieved from http://www.education.gov.uk/

European Commission. European Reference Framework Education and culture Lifelong Learning Programme: Key Competencies for Lifelong Learning. Luxembourg: Office for Official Publications of the European Communities. Retrieved from http://www.britishcouncil.org/ sites/britishcouncil.uk2/files/youth-in-actionkeycomp-en.pdf

European higher Education Area. The Bologna Declaration of 19 june 1999. Retrieved from http:// www.ehea.info/Uploads/about/BOLOGNA DECLARATION1.pdf

Камберски, К. (2000). Предучилишното $u$ основното воспитание и образование во Република Македонија, Скопје: Филозофски Факултет.

Министерство за образование и наука на Република Македонија (2005). Национална програма за развој на образованието во Република Македонија: 2005-2015, Скопје: Retrieved from http:/www.mon.gov.mk/images/banners/ web banners/Nacionalna $\% 20$ strategija $\% 20$ za\% $\%$ oobrazovanieto\%202005-2015.pdf

PGCE (Post Graduate Certificate of Education). Retrieved from https://getintoteaching.education. gov.uk/explore-my-options/training/universityled-postgraduate-training

Gassner, O. Kerger, L. Schratz, M. (2010). First ten years after Bologna. Bucureşti: Editura Universităţii din București. Retrieved from http://www.unikassel.de/einrichtungen/fileadmin/datas/einrichtungen/zlb/Akt__ENTEP_Book.pdf

Comission of the European Communities. Commission staff working paper: Schools for the $21^{\text {st }}$ century. Brussels 2007.

European Commission Education and Training, School education, Key Competencies. Retrieved from http://ec.europa.eu/education/policy/school/ competencies_en.htm

Никодиновска, Банчотовска, С. (2004). Професионалните компетенции на наставниците во основното образование во Република Македонија, Докторска дисертащија, Скопје: Филозофски факултет, Институт за педагогија.

Potkonjak, N. i dr. (1968). Pedagogija. Zagreb: Matica Hrvatska. 